Playing God or Participating in God? What Considerations Might the New Testament Bring to the Ethics of the Biotechnological Future?

Professor Grant Macaskill, University of Aberdeen

Address: School of Divinity, History and Philosophy,

University of Aberdeen, King's College, Aberdeen, UK. AB24 3UB

Email: grant.macaskill@abdn.ac.uk

\title{
Abstract
}

The Bible is normative for all Christian theology and ethics, including responsible theological reflection on the biotechnological future. This article considers the representation of creaturehood and what might be labeled 'deification' within the biblical material, framing these concepts in terms of participation in providence and redemption. This participatory emphasis allows us to move past the simplistic dismissal of biotechnological progress as 'playing God', by highlighting ways in which the development of technology and caregiving are proper creaturely activities, but ones that must be morally aligned to the goodness of God. Framing our approximation of divine character in terms of 'deification' highlights its relational and soteriologically defined shape, preventing us from conceiving its attainment in any way that is loosed from the death and resurrection of Jesus Christ. The discussion allows us to affirm the pursuit of biotechnological research, but to recognize that it is unable by itself to accomplish certain ends, and that it must be pursued in alignment with the standards of goodness by which God loves his world.

Keywords: biotechnology, creaturehood, deification, New Testament, Wisdom, participation.

The Bible is normative for all Christian theology and ethics: it governs and resources all matters of life and thought, which is why biblical scholarship remains relevant to our thinking about developing technology that would have been unimaginable to its authors. The questions raised by the discussion of the biotechnological future, 
however, immediately confront us with the need to avoid overly simplistic conceptions of how the biblical material functions within our theological-ethical reflection. We will not find the issues under consideration represented in simple terms within the biblical texts, for they have arisen within the unprecedented technological environment of the present time, which makes the technological future possible, and which constitutes a new context of progress that would be unimaginable to our ancestors. To 'think biblically' about such matters requires more than the simple exegesis of obviously relevant texts, since few texts will be 'obviously relevant.' Instead, it requires us to think of how the Bible, in all its complexity of genres and styles (narrative, prose, poetry, prophecy, proverb and, in the smallest proportion, commandments) might suggest patterns of thinking that can be brought to bear on the technological present and future, particularly as these are related to the reality of a God whose existence transcends time, but who is in some sense involved in the lives of creatures. The technological present and future are themselves contextualized by the reality of the one "who was, and is, and is to come" and it is this constant that allows us to move from ancient Scriptures to contemporary reflection, but never in a way that loses sight of the complexity of the task.

I begin with this observation because it frames what I will seek to do in what follows, as I offer some reflections on a number of biblical passages that might contribute to our theological discussion of the technological future. It also, though, frames one of the problems that always attend discussions of the biotechnological future, and to which my title alludes: discussions are often closed prematurely with the accusation that science is 'playing God', a concept seldom discussed in relation to the rich ways in which humans are represented as being and acting like God, or as participating in his providential work, or in relation to the specific ways in which 'playing God' is represented in Scripture.

${ }^{1}$ This title is encountered in Revelation 1:4, 1:8 and 4:4, used both of God and Jesus. It is also encountered in Aramaic translations of Deuteronomy 32:39 and arguably reflects Jewish speculation on the significance of the divine name, the Tetragrammaton, which appears connected to the verb hyh, 'to be'. Regardless of the connection with the Tetragrammaton, the title indicates a recognition of God's uniquely transcendent relationship to time, as a function of the created order. 
My intention in what follows, then, is to consider the core themes of creaturehood and deification-which were the substance of our discussions at the conference from which this volume arose-with a view to introducing some more nuanced categories of participation in the life and activity of God. These will allow us to speak of the moral issues involved in the technological future in more subtle ways that might allow us to embrace technological advancement, while still critically considering the values at work within it. Are these consistent with the character of the God who creates and provides, and hence appropriate for those who seek to participate in his goodness? Along the way, I will highlight some examples in which the problem of 'playing at God' using technology (albeit primitive) is 'fleshed out'. The issues there, as we shall see, are quite different to those that we commonly dismiss with this label.

\section{On Creaturehood.}

I begin with a rather dense thesis statement, the elements of which will be explored and, where necessary, defended in what follows. ${ }^{2}$ It is a statement that summarises what I consider to be the key moves in the biblical material, considered as a canonical whole that includes both Old and New Testaments.

To be a creature is to be an object of God's creative and providential activity, an activity that is now seen to be mediated by, through and in the person named as Jesus Christ, 'by whom and for whom all things were made, and in whom they hold together' (Colossians 1:15-17). Creatures participate in a creation that is finite - temporally, spatially and potentially—which enjoys life by its fellowship with an eternal God who has unlimited life within himself, and who gives this without expectation of a return in kind. To be a creature is to live in such dependence, and within such limits, whether consciously or not. Because we are considering the relationship between the finite and the infinite, the time-bound and the timeless, the mortal and the immortal, and because this relationship is challenged by the powers of chaos and evil, we must think about this

2 This thesis statement was the core of my contribution to the discussion of creaturehood at the symposium in Oxford from which this volume arose. 
eschatologically. But, precisely because one side of the Creator-creation relationship transcends time, eschatology can never be conceived in simply linear terms: the lamb was slain, and election enacted, before the foundations of the world (Ephesians 1:4; 1 Peter 1:20; Revelation 13:8). Because of this, eschatology is represented in the disruptive terms of incarnation and parousia, that puncture any notion that within the flow of time, creatures - or the creation as a whole - can progress to the state of perfection apart from the active and alien presence of God, mediated by Jesus Christ and realised by the Spirit. The limits of our being and potentiality, then, lie not just in our physical state and its frailty, but in the nature of our dependency upon God. To seek to overcome those limits apart from that dependency, to aim to break our dependency upon God, is at the heart of what it means 'to fall.'

This statement acknowledges that the Bible uses creational language, not just of the original creative work by which the world was formed and filled (described in Genesis 1-2, Job 38; Psalm 104; Proverbs 8:22-31), ${ }^{3}$ but also of the formation of each new creature:

For it was you who formed my inward parts;

you knit me together in my mother's womb.

14 I praise you, for I am fearfully and wonderfully made.

Wonderful are your works;

that I know very well.

My frame was not hidden from you,

when I was being made in secret, intricately woven in the depths of the earth. (Psalm 139:13-15) ${ }^{4}$

${ }^{3}$ It is important to recognize that there is not a single 'creation account' in Scripture, but rather multiple different accounts that complement one another canonically. On this point, see William P. Brown, The Seven Pillars of Creation: The Bible, Science, and the Ecology of Wonder (Oxford: Oxford University Press, 2010).

${ }^{4}$ Unless otherwise indicated, all quotations are taken from NRSV (New York: Harper Collins/National Council of Churches, 1989). 
While the language encountered here speaks of God's involvement in the formation of a new living creature, a process that involves the participation of the parents, we encounter also language that speaks of God's involvement in the formation and ordering of the inanimate parts of creation, whether the mountains and watercourses that are placed by him (Psalm 104), or the flowers that are clothed by him (Matt 6:2830 and parallels).

Importantly, the concept that we name 'providence' is frequently interwoven with these descriptions of God's creative activity. The terms 'creation' and 'providence' do not designate the same thing - a point that is important to stress since deistic accounts often naturalised the latter and made it a function of the former. ${ }^{5}$ Rather,

The Christian doctrine of providence concerns God's continuing relation to the world that he has created. In his continuing work of providence, God acts upon, with and in each particular creature and created reality as a whole. As God so acts, God preserves created reality and being, maintains its order and directs it to the end that he has established for it. God's providence enacts his enduring love for that which he has made and shows him to be a faithful Creator. ${ }^{6}$

This statement captures nicely what we see in the biblical accounts of God's creative activity, which move fluidly from descriptions of formation to those of God's continuing involvement in the lives of his creatures. They are not simply made and then given autonomy, but are set within a community of creation ${ }^{7}$ that continues to

5 This view was a feature of deist accounts of providence. For a surprisingly sympathetic treatment of these, see Katherine Sonderegger, 'The Doctrine of Providence', in The Providence of God (ed. Francesca Aran Murphy and Philip G. Ziegler; London: T\&T Clark, 2009), pp. 145-9.

${ }^{6}$ John B. Webster, 'Providence', in Mapping Modern Theology: A Thematic and Historical Introduction (ed. Kelly M. Kapic and Bruce L. McCormack; Grand Rapids, MI: Baker, 2012), p. 203.

${ }^{7}$ For this language, and its significance, see Richard Bauckham, The Bible and Ecology: Rediscovering the Community of Creation (Waco, TX: Baylor University Press, 2010), in toto. 
derive its life and blessing from the presence and activity of God, who 'clothes', 'feeds', 'holds', 'binds', 'looses', et cetera.

It is worth stressing that such language is used of God precisely because these verbs are comprehensible to creatures who perform them in their own lives and activities. In the case of Job 38-41, the verbs are typically used to highlight the uniqueness of God's sovereign intimacy with the whole of the created order: God alone does all of these things. But the contrast with finite creatures is effective because they know what it is to do similar things within the limits of their own natures: they feed, they hold, they bind, they loose, but they do none of these in the same way, or to the same extent, or to the same things as God. They act in God-like ways, but they are creatures and not gods. Their activities are always those of contingent things, dependent upon something beyond themselves, even if what they are dependent upon is unknown to them. ${ }^{8}$ This is core to the concept of participation that we will explore further in relation to deification: creatures participate in the mystery of providence, reprising in their own creaturely and dependent way the verbs of divine activity, but properly without any intent to arrogate divine status to themselves.

Importantly, God's creative and providential activity is often represented using technological imagery, even if the technology in question is relatively primitive. As creator, God is represented as an 'architect' or 'builder', his work shaped and ordered by his Wisdom, which is often represented as a separate, female creature who guides

${ }^{8}$ For a theological exposition of this distinction between Creator and creatures, affirming the place of creatio ex nihilo in a proper account of creaturehood, see John Webster, " "Love Is Also a Lover of Life": Creatio ex nihilo and Creaturely Goodness', Modern Theology 29 (2013): pp. 156-71. In particular, the distinctions Webster notes on pages $162-5$ highlight that whatever points of correspondence can be established between creaturely activities and the creational work of God (particularly with his ordering and developing of the stuff he has made, as in most of the Genesis 1 account), there is no analogue to the act of creation ex nihilo, which consequently defines all relations between created things and God. 
and orders the divine activity. ${ }^{9}$ In accordance with his Wisdom, he stretches out the heavens, applies plumb lines to the world, allocates resources. The world is not chaotic, then, because it is ordered by Wisdom, who is re-identified with the person of Jesus in the New Testament writings. ${ }^{10}$ Human works of architecture and construction are corresponding acts of creaturely creation, which may have artistic qualities that are derived from the presence of the divine spirit within them, ${ }^{11}$ and may serve the purposes of caregiving and enhancement of life: in the 'houses' that they have built, people can be sheltered from the weather, protected from the chaos, and can occupy spaces that bring comfort, or pleasure, or are home to acts of worship. ${ }^{12}$

Of course, the technology of architecture is at the heart of one of the great biblical stories of 'playing God' - the account of the Babel tower (Genesis 11) — but it is interesting that what is at stake here is not the use of technology, as such (although the passage makes detailed reference to the technology at work, the use of bricks and bitumen). Rather, what is at stake is the intention to build a tower that will occupy the space associated with deity: the tower is to have 'its top in the heavens' (Genesis 11:4). This is very simply and very straightforwardly an attempt to arrogate the status of gods to the human architects; it is not oriented towards the wholesome goals of giving care and bringing joy. Here, the creatures do something God-like, but precisely to reverse their relationship to God: they will deny their contingency and assume autonomy, arguably in rejection of the divine command to fill the earth (Genesis 1:28, 9:1), but certainly in an effort to exceed their limits apart from dependency upon God. Importantly, within the spread of activities that God directs towards his creatures and in which they participate, we encounter the language of healing. One of the most important examples of this is found in Deuteronomy 32:39, which is one of a cluster

${ }^{9}$ E.g., in Proverbs 8. Jewish traditions, such as the Genesis Rabbah, read Proverbs 8 together with Genesis 1 and identified the Wisdom by which the world is ordered with the Torah.

${ }^{10}$ For an overview and discussion, see Ben Witherington III, Jesus the Sage: The Pilgrimage of Wisdom (Edinburgh: T\&T Clark, 1995).

${ }^{11}$ See Exodus 31:1-11.

12 The relationship between human creativity and divine creativity, including their aesthetic dimensions, is explored thoroughly by Trevor Hart, Making Good: Creation, Creativity, and Artistry (Waco, TX: Baylor University Press, 2014). 
of particularly important statements of monotheism in the Old Testament that use the expression 'I, even I' ('ani hu in Hebrew, ego eimi in Greek).

See now that I, even I, am he;

there is no god beside me.

I kill and I make alive;

I wound and I heal;

and no one can deliver from my hand. (Deut 32:39).

Here, the emphasis is on the uniqueness of God's freedom and sovereignty, but in other places (such as Psalms 41:3, 103:3), the emphasis falls on the intimacy of God's caregiving to the afflicted. Interestingly, in Ezekiel 47:12 - in an image that is reprised in Revelation 22:2 - God provides healing through another creation, the leaves of the tree that grow on either side of the river that flows from the altar in this eschatological vision. Here, the image of healing is medical and ecological, but God is not the doctor whose hands will bring healing (as he is in Job 5:8, or in Psalm 147:3), but is the creator who gives to his creatures a means to treat each other's wounds.

Within the gospel accounts, the representations of Jesus as a healer draw strategically upon the promises and 'servant songs' of Isaiah. Jesus' response to the disciples of John - who ask, 'Are you the one who is to come, or are we to wait for another?'-is generally seen to draw upon the expectations of healing in Isaiah 26:19, $29: 18,35: 5-6$ and $61: 1 .^{13}$

'Go and tell John what you hear and see: the blind receive their sight, the lame walk, the lepers are cleansed, the deaf hear, the dead are raised, and the poor have good news brought to them.' (Matt 11:5-6)

Interestingly, elsewhere in Isaiah, the commissioning of the Servant to bring healing is linked to the creative and providential work of God:

5 Thus says God, the LORD,

${ }^{13}$ See Grant Macaskill, Revealed Wisdom and Inaugurated Eschatology in Ancient Judaism and Early Christianity (Leiden: Brill, 2007), 136-8. 
who created the heavens and stretched them out,

who spread out the earth and what comes from it,

who gives breath to the people upon it

and spirit to those who walk in it:

6

I am the LORD, I have called you in righteousness,

I have taken you by the hand and kept you;

I have given you as a covenant to the people,

a light to the nations,

to open the eyes that are blind,

to bring out the prisoners from the dungeon,

from the prison those who sit in darkness.

The point is important. On one hand-or in one nature-Jesus embodies the will of God to bring healing, and mediates divine care of the sick creature; on another-in his other nature-he embodies a creaturely participation in the community of creation, including its obligation to pursue wholeness and healing. His healing activity is, at once, that of the God who acts to heal the damaged things within his creation and of the creature who acts to care for his fellows. As a creature who participates in the will of God, he pursues healing. His response to the reality of suffering is not passive acceptance, but is one of transformative care. The parallels that can be drawn between such miraculous or supernatural actions and biotechnological interventions are limited, of course, but there is an important point of contact: affirming God's involvement in the natural order, and his sovereignty over processes of sickness and suffering, does not lead to a passive acceptance of the effects of our mortal weaknesses. Creatures who participate in God's providence participate in his works of healing.

Importantly, though, the centrality of the cross to the New Testament, and its identification as an event taken into the life of God himself, prevents us from simply speaking about suffering in negative terms, as if the ending of suffering is identical to goodness. Because suffering has been taken into the life of the God who has become flesh, our suffering can be participatory and can take on a freshly positive significance. We can experience a form of koinonia ('fellowship' or 'partnership') with the sufferings of Christ (Philippians 3:10) and can, indeed, 'complete' the sufferings of Christ in our own flesh (Colossians 1:24). The significance of such 
language is only rightly grasped when understood in relation to the resurrection and ascension of Jesus the Creator-creature, as seen in Colossians 1:15-23, where the author engages in some language play around the word firstborn: the Son is firstborn of all creation and the firstborn of the dead. This eschatological dimension reframes both suffering and healing: death and mortality is taken into the life of God, that it may be transformed. Now, placed under the feet of Christ, death is no longer the enemy, but is a servant (1 Cor 15:25-6). ${ }^{14}$

Much of what we have considered to this point has been focused on humans, but the description of God's creative and providential activity that we encounter in Job 38-41 is striking for its cosmic expanse and what we might label its humble details: God is involved in everything, and in the lives of all creatures, from the huge to the tiny. The capacity of the creational order to instruct those who reflect upon its patterns, seen in a book like Proverbs, which will derive lessons from ants and lizards, reflects this saturation of the natural order with the acting presence of God and his Wisdom.

One point is easily overlooked in the mass of detail encountered in Job 38-41, but it emerges more obviously from the selection of providential works described by Jesus in Matthew 6:25-30/Luke 12:22-8. God's providential care is directed towards those things that have no utility or capital value. He feeds not just doves and lambs, which can be sold, to be offered in worship and consumed, but also the ravens (Luke 12:24). ${ }^{15}$ Within the context of Jewish agrarian society, this is striking, for the raven would be categorised as an unclean bird and its scavenging would often constitute a nuisance. ${ }^{16}$ Similarly, God nourishes and clothes not just the crops that can be harvested, sold, eaten and offered in worship, but the lilies of the field. These may be pretty, but they cannot feed a family, and would not be sold for trade as they are today.

${ }^{14}$ Death is represented here as the last enemy to be placed under the feet of Christ. The verb used in 15:26, katargeō is often translated as 'destroyed', but might better be rendered with its common meaning of 'nullified'.

${ }^{15}$ Matthew has the more neutral 'birds of the skies'.

${ }^{16}$ I offer this as a personal insight, from my younger days as a shepherd: we would often find weak or sick lambs whose eyes or rectums had been picked out by ravens. The sight of ravens or other crows over lambing fields was often cause for concern. 
In the socio-economic context of Jesus' teaching in Galilee, such an affirmation of God's care for those things without capital or utilitarian significance would be striking. While there is some debate about the distribution of wealth among Jewish communities, there is no doubt that there was widespread unemployment and dispossession of property. ${ }^{17}$ Many had become 'have nots', seeking day labour where they could find it, a situation reflected in several parables. To speak of God's care for those who have no productive role within the community is a powerful thing in such a context.

It is also, perhaps, of significance to the discussion at hand that this providential care is attached to the mortal and temporary. It is attached to the bird that falls to the ground and the vegetation that is here today and gone tomorrow. The value of these things does not require their lives to be extended, for their place within the order of creation is not a static one. The point must be treated with care, and related to the significance of Jesus' resurrection as an event that takes place within the created order, by which the immortal life of God transforms the weakness of dust and brings it newly visible possibilities, for which the creation as a whole groans in expectation (Romans 8:19-23). Nevertheless, it cuts across many of the values that drive the pursuit of longevity or freedom from disease in contemporary research: it is not only a life liberated from mortality and weakness that can be considered 'worthwhile'.

This biblical material on creaturehood provides an important touchstone for theological reflection on the technological future. It is wrong to throw around accusations that technological intervention is a matter of playing God: technology is a kind of creative reflection of divine architecture, and can be oriented towards the proper ends of caregiving and proper pleasure. Technology can serve the goals of joy. There is something rather arbitrary about the decision to see certain kinds of technological intervention, particularly at the cellular or genetic level, as less defensible than the construction of a weatherproof wall or a beautiful church.

The more nuanced question to ask is whether our development of biotechnology reflects divine values and therefore participates in the goodness of God's providential work. Our application of technology to those labelled as disabled, for example, may

${ }^{17}$ See the range of essays in David A. Fiensy and Ralph K. Hawkins, The Galilean Economy in the Time of Jesus (Atlanta, GA: Society of Biblical Literature, 2013) for the spread of opinions, but note the general agreement that poverty was widely found. 
be determined by a viewpoint that considers them to have value only if they can be productive, if they have utility and hence capital value of some kind. As a consequence of this, we may decide that technology needs to eradicate certain gene types, either by gene therapy or by termination of the line. This has been a notorious part of the discussion of Down's Syndrome in recent years ${ }^{18}$ and was, of course, a prominent element in the eugenics movements of the early $20^{\text {th }}$ century. But God's providence disdains matters of utility and capital, clothing lilies and feeding scavengers. Moreover, those acts of providence involve a distribution of resources that extends care to the socially marginal, the things without utility or capital value, and is driven by beauty as well as by function: it is important that the cosmos is full of beautifully useless things. The point is made - and made often - that for all the increasing affordability of technology, the assigning of capital resources to technological projects devoted to ending suffering or prolonging lifespan is one that typically benefits only a small, elite fraction of society. The moral issues at work, then, may be less those of the technologically sensational headlines and more those of the mundane decision of how wealth and resources can be used responsibly, lovingly and prayerfully.

\section{On Deification}

The technical vocabulary used of deification or divinisation in the later Christian tradition (theosis, theopoesis, et cetera) is not found within the Bible itself. This terminology was developed by the later tradition in connection to a composite soteriological account that made use of certain biblical texts in which figures other than God are described (positively and properly) using the language of divinity. The key text for the early tradition was John 10:34, as it quotes Psalm 82:6.

Jesus answered, "Is it not written in your law, 'I said, you are gods'?

18 See, for example, the article published in The Guardian 'Richard Dawkins: 'immoral' not to abort if foetus has Down's syndrome', published $21^{\text {st }}$ August, 2014. Available online: https://www.theguardian.com/science/2014/aug/21/richarddawkins-immoral-not-to-abort-a-downs-syndrome-foetus, retrieved on 17 th $^{\text {th }}$ May 2018. 
Modern biblical scholars might complain about the Patristic exegesis of this text, but the Fathers' use of it was not a crude misappropriation. Rather, the text functioned to anchor a more comprehensive reading of the ways in which salvation is represented in the New Testament as involving transformation and glorification, with fleshly creatures coming to share in the life of the heavenly realm. John 10:34 may have been the anchoring text, but the concepts and imagery came more substantially from other parts of the Fourth Gospel - in which believers are filled with the light and life of God (John 1:4, 8:12, 12:46, et cetera) and are drawn into glorious and unitive fellowship with the triune God (John 17:22-3) - and passages throughout the New Testament that represent those whom God has saved as participating in the heavenly world (Ephesians 2:6, Hebrews 4:14-16, 12:12-24).

Some current biblical scholarship has either located this kind of imagery within a broader set of ancient beliefs in the apotheosis of human beings ${ }^{19}$ or has seen it as growing out of particular Jewish beliefs concerning angels: the imagery constitutes a form of 'angelomorphism' and the representation of Jesus as 'divine' is largely of the same order. ${ }^{20}$ I consider this to be imprecise, and to rest on a slack analytical use of language, at least as far as the biblical material is concerned. Any parallels drawn between glorified humans and angels are of an analogical kind, rather than constituting an identification of transformed humans as angels. Participation in the heavenly realm and liturgy is one such point of analogy, in which any correspondence is kept in perspective by difference. As David Moffitt has highlighted, this is a central theme in the book of Hebrews, where the distinction between the exalted Jesus as a human being and the angelic figures who also occupy heaven is stressed. ${ }^{21}$

${ }^{19}$ E.g., David Litwa, We Are Being Transformed: Deification in Paul's Soteriology (Berlin: De Gruyter, 2012).

${ }^{20}$ Such language permeates Crispin Fletcher-Louis, All the Glory of Adam: Liturgical Anthropology in the Dead Sea Scrolls (Leiden: Brill, 2002). The concept of angelomorphism has been studied with greater precision with respect to its function in the Patristic tradition by Bogdan Bocur, Angelomorphic Pneumatology: Clement of Alexandria and Other Early Christian Witnesses (Leiden: Brill, 2009).

${ }^{21}$ David Moffitt, Atonement and the Logic of Resurrection in the Epistle to the Hebrews (Leiden: Brill, 2013). 
A similar issue is attached to the popular 'Adam Christology' approach, in which the glory of believers is understood in terms of the recovered glory of Adam, lost at the Fall and-it is claimed-widely reflected in Jewish literature from the Second Temple period. ${ }^{22}$ I have challenged this approach on multiple occasions, and I return to it here in order to stress the issue that is at stake in the discussion of deification. The Adam approach, like the angelomorphic one, understands the glory that is spoken of to be a property of the creature itself, an ontological quality that has been lost and recovered or newly gained. As Carey Newman has highlighted, however, the language of glory $(k a v o \bar{d}$, doxa) is used particularly in the biblical traditions of God; where humans, or other creatures, are glorified, it is because his glory is shared with them. ${ }^{23}$ Glory, in other words, is enjoyed as a communicated reality, experienced by divine presence, rather than as a function of ontological condition. There may be a genuine ontological transformation, but this is a corollary of glorifying divine presence. The application of glory language to Jesus, as Newman highlights, reflects his identification not just with but as God; the sharing of that glory with us is a consequence of Christ's mediatory work, realised by the presence of the Holy Spirit. The representation of our glorification as taking place 'in' and 'with' Christ (see, e.g., Romans 8:17; Ephesians 2:6-10) reflects this.

This is important, because it highlights the significance of sin as a dynamic that disrupts this presence. And this, in turn, speaks into the ways that we conceive the actualisation of the transformation in view. It can come only by deliverance from the sin that turns us inwards, and that separates us from God. Within the New Testament, this deliverance is defined by two events, the Christ event (incarnation, death, resurrection and ascension) that brings the outpouring of the Spirit, and the parousia that brings this event to its still-to-be-realised consummation. The remaining hope for the latter places limits on our expectations of progress in this life: our scientific accomplishments may break open all kinds of new possibilities, and may eradicate all kinds of problems - for which we may give thanks - but the testimony of Scripture would direct us away from any expectation that they will eradicate the problem of sin.

${ }^{22}$ See my Union with Christ in the New Testament (Oxford: Oxford University Press, 2013), Chapter 5.

${ }^{23}$ Carey C. Newman, Paul's Glory Christology: Tradition and Rhetoric (Leiden: Brill, 1992). 
However god-like our technologically enhanced selves might appear to those who have gone before, we will not attain perfection until that point. Indeed, it invites us to be wary of interventions that see themselves as antidotes to sinful or negative behaviour, and cautions us that the values we apply to such corrective developments may themselves be compromised by the reality of sin. The cautionary significance of this to the contemporary technological situation is important: much is done with the best of intentions, and developers undoubtedly believe themselves to be acting in the best interests of humanity, but these beliefs may be distorted by sin's noetic effects. The biblical conviction that only with the parousia will the presence of God be experienced without the compromising effect of sin provides a key point of reference in our evaluative framework.

Once these points are noted, however, it is worth recognising that the kind of participatory language that is at the heart of concepts of deification can rightly be understood in a way that affirms involvement in this world. As we noted in relation to the concept of creaturehood, to be glorified by the presence of the holy spirit is to share in God's providential activity. Perhaps surprisingly, this is one of the overtones in 2 Peter 1:4.

Thus he has given us, through these things, his precious and very great promises, so that through them you may escape from the corruption that is in the world because of lust, and may become participants of the divine nature. (1 Peter 1:4).

This verse is often regarded as one of the great articulations of theosis, but it is relatively late in the tradition that we begin to find it used in this way. ${ }^{24}$ At first glance, it would appear to suggest something rather gnostic in tone, and older New Testament scholarship often regarded it as compromised by 'Greek' views of the physical world. Specifically, though, the problem identified in the world is the 'corruption of lust' (epithymia phthoras), not its physicality: there are sinful desires from which we need to be delivered, but this is not the same as saying that we need to

${ }^{24}$ See Grant Macaskill, Union with Christ in the New Testament (Oxford: Oxford University Press, 2013), p. 66. Origen is the first of the Fathers to make significant use of 2 Peter 1:4 in relation to deification. 
be delivered from all desires or all physicality. Some desires, some appetites, some uses of the body can be good.

Further, the participation described is not necessarily one of absorption or sublimation, but rather of covenant partnership. The point has been made by Wolters that the specific construction found here-with the nominative koinonoi and a genitive expression, theias phuseos - is typically encountered in contexts where koinonos has its common meaning of 'partner' ${ }^{25}$ This meaning is, potentially at least, covenantal: the partnership is formalised in some sense by the agreement between parties to work together. The fact that there are typically covenantal words found in the immediate context, such as the language of 'promise' or of 'calling/election', may support the idea that the participation spoken of here is one of partnership.

This takes us into different interpretative territory: now deification is not about fleeing or transcending the world, but about living rightly within it, in covenant partnership with God, seeking to bring about his will within it, and praying, 'your will be done on earth as in heaven.' Once we acknowledge this, then the range of ways in which the covenant (and the law that was at its core in the Old Testament) bear upon the responsible practices of technology take on fresh significance. Roofs are built with balustrades to protect occupants from injury, fields are ploughed and then harvested in ways that leave space for wildlife to glean, the land is given its own Sabbath to recover from the strains of agricultural activity. Technology exists, albeit in relatively primitive form, and may be used, but in ways that are aligned with the will of God who creates and provides. All of this is governed and regulated by the laws of the covenant, and while those laws may no longer be in operation, they point to what it means to be a partner with the covenant God. It is not technological shutdown, but technology used with care and submission.

A final point is worth making on the topic of deification. There are senses in which all creation participates in the life of the Son who assumed a creaturely nature: in him, all things hold together (Colossians 1:17). This was an important theme in the incarnational theology of Athanasius and the later Fathers. ${ }^{26}$ But there is also a distinct way in which those who pray and partake of the sacraments participate in the

${ }^{25}$ Albert M. Wolters, "'Partners of the Deity”: A Covenantal Reading of 2 Peter 1:4,' Calvin Theological Journal 25 (1990): pp. 28-44.

${ }^{26}$ See $C$. Gentes 3:41. 
life of God. ${ }^{27}$ At the heart of Christian life, the sacraments define and probe our thought and theology, and they do so by affirming the soteriological victory accomplished through an act of suffering and death. Whatever else this may do, it recontextualises the human pursuit of freedom from suffering and extension of life through technology. The scientist who has been baptised-who has, in a sense, already passed through death — and who partakes of the Eucharist, giving thanks for the death and resurrection of Jesus Christ, will evaluate mortality rather differently from one who has no redemptive categories in which to locate death,

\section{Conclusions: Can we Participate in God and the Technological Future?}

'Participation' has become a prominent term in recent biblical studies, though one that is often thrown around without much precision. ${ }^{28}$ It is also, of course, a key concept in the discourse around deification in Christian theology. What I have sought to highlight in this discussion is that the term can meaningfully be applied to the creaturely involvement in the providential working of God, in which we are recipients of divine benevolence who can, in turn, manifest, share and replicate that goodness in their relationships with the community of creation in which they exist. As creator and Lord of providence, God (now identified with the person of Jesus Christ) is represented in terms that lend themselves to reflection on technology: he designs, builds and manages the structures of the cosmos. The language is meaningful to us because we also design and build things, as we reprise divine creativity and care in our own lives. Where such participation moves into the sinful territory of 'playing God' is specifically the point where it seeks to assert its god-likeness without reference to God himself, or even in hostility to God, seeking to arrogate to itself final

\section{${ }^{27}$ Norman Russell, The Doctrine of Deification in the Greek Patristic Tradition} (Oxford: Oxford University Press, 2002), notes this distinction in Origen (p. 147, n. 55), and again in Athanasius (p.177) by which those who actively partake of the sacraments and the life of faith enjoy something different to the ontological participation of those who are bound simply by creaturely kinship to the Incarnate one. See also my comments in Union with Christ, 302-4.

${ }^{28}$ A notable recent exception to this is Susan Eastman, Paul and the Person: Reframing Paul's Anthropology (Grand Rapids, MI: Eerdmans, 2017). 
authority, naïve to the reality of sin as something that corrupts our capacity to judge morally. Once the sweeping dismissal of 'playing God' is passed, and its limited value to the discussion of biotechnological progress is recognised, technological emulation of divine creativity faces a more finely-grained and subtle set of moral evaluations: are we using our finite resources in a way that is aligned with the goodness of God, including his care for the weak, or in a way that is compromised by the subtleties of structural sin.

Articulating the issues in this way highlights the place of soteriology in our discussions of the technological future, whether we deploy the term deification in relation to this or nor. The existence of creation, in all of its past and all of its future, always rests on God's giving of himself into it, something now identified with the Incarnation of Jesus Christ. By this, God not only makes himself present with the creation, as its Emmanuel (Matt 1:23), but also addresses the problem by which we are alienated from that presence, the sin that turns us inwards, away from the community of creation in fellowship with God, and that distorts capacity to know right from wrong. In fellowship with the one by whom all things were made and who has reconciled all things to God (Colossians 1: 15-20), we flourish, living again 'with the grain of the universe. ${ }^{29}$

${ }^{29}$ Alluding to the title of Stanley Hauerwas, With the Grain of the Universe: The Church's Witness and Natural Theology (Grand Rapids, MI: Brazos, 2001). 